\title{
Emotions in the Hebrew Bible: A Few Observations on Prospects and Challenges*
}

\author{
Paul A. Kruger (University of Stellenbosch)
}

\begin{abstract}
Although there has been significant progress in the study of emotions in the $H B$ in recent years, a variety of matters still need attention or serious reflection. This article addresses some of these. Aspects that are focused on include: (1) the designation "emotion" and what it entails in a HB context; (2) the limitations of the original psychophysical approach; (3) the cognitive approach and the question of a dominant conceptual metaphor; (4) the social-constructionist view of emotions and the problems of translating emotional communication; and (5) some issues related to gender and emotion.
\end{abstract}

Keywords: psychophysical approach, cognitive approach, dominant conceptual metaphor, social-constructionist view, gender and emotions

\section{A INTRODUCTION}

The topic of emotion has lately become a popular theme for research. Disciplines across the spectrum of the social sciences have each come up with their view on the subject, conducted in terms of their specific scientific perspective. One often comes across titles relating to anthropological, ${ }^{1}$ sociological ${ }^{2}$ and cultural $^{3}$ issues dealing with emotions. Studies focusing attention on emotions in the $\mathrm{HB},{ }^{4}$ the deuterocanonical literature, ${ }^{5}$ other related $\mathrm{ANE}^{6}$ and classical

* To cite: Paul A. Kruger, "Emotions in the Hebrew Bible: A Few Observations on Prospects and Challenges," OTE 28, no.2 (2015): 395-420. DOI: http://

dx.doi.org/10 .17159/2312-3621/2015/v28n2a10

1 Kay Milton and Maruška Svašek, Mixed Emotions: Anthropological Studies of Feeling (New York: Berg Publishers, 2005).

2 Monica Greco and Paul Stenner, Emotions: A Social Science Reader (New York: Routledge, 2008).

3 Jennifer Harding and E Deidre Pribram, Emotions. A Cultural Studies Reader (New York: Routleđge, 2009).

4 For some of the studies only of the last decade, cf, Andreas Wagner, Emotionen, Gefühle und Sprache im Alten Testament: Vier Studien (KUSATU 7; 'Waltrop: H. Spenner, 2006); Silvia Schroer and Thomas Staubli, "Biblische Emotionswelten," KatB 132/1 (2007): 44-49; Andreas Wagner, Anthropologische Aufbrüche: Alttestamentliche und interdisziplinäre Zugänge zur historischen Anthropologie (FRLANT 232; Göttingen: Vandenhoeck \& Ruprecht, 2009); Christian Frevel, Biblische Anthropologie: Neue Einsichten aus dem Alten Testament (QD 237; 
disciplines ${ }^{7}$ have also not lagged behind. A wide variety of issues are addressed in which not only textual evidence has been investigated, but also iconographical sources. ${ }^{8}$

A major problem in the study of emotions in a "dead" language such as Biblical Hebrew, though, is that most of the emotion scenarios (mostly attested in the poetic books) are cast in highly figurative language. Attempts to determine which specific emotion is being described or communicated in any given case are extremely difficult or even impossible. Ortony and Fainsilber regard this as a typical peculiarity of "emotion talk" where an intense feeling or sentiment is so difficult to convert into a literal description that the only option seems to be to resort to metaphorical speech. In their view:

Freiburg: Herder, 2010), and Bernd Janowski, Der Ganze Mensch: Zur Anthropologie der Antike und ihrer europäischen Nachgeschichte (Berlin: Akademie Verlag, 2012).

${ }^{5}$ Renate Egger-Wenzel and Jeremy Corley, Emotions from Ben Sira to Paul (DCLY; Berlin: De Gruyter, 2011).

6 Recent publications include a 2003 doctoral dissertation submitted at the University of Göttingen by María Isabel Toro Rueda, "Das Herz in der ägyptischen Literatur des zweiten Jahrtausends v. Chr. Untersuchungen zu Idiomatik und Metaphorik von Ausdrücken mit jb und ḩ3tj." (Ph.D. diss., University of Göttingen, 2003) [cited 28 May 2015]. Online: http://d-nb.info/972097295/34. This study investigates metaphors, idioms and emotions relating to the heart in the Egyptian culture. For the Ugaritic culture, cf. Mark S. Smith and Wayne T. Pitard, Introduction with Text, Translation and Commentary of KTU/CAT 1.3-1.4 (vol. 2 of The Ugaritic Baal Cycle; Leiden: Brill, 2009), especially the paragraph: "Excursus I: Liver/Innards $(k b d)$ and heart $(l b)$ in West Semitic Expressions of Emotions," 164-174; for Mesopotamia, see Ulrike Steinert, Aspekte des Menschseins im Alten Mesopotamien: Eine Studie zu Person und Identität im 2. und 1. Jt. v.Chr. (CunM 34; Leiden: Brill, 2012), who often refers to the close connection between body parts and the expression/experiencing of emotions. Especially enlightening is her extensive chapter of more than 100 pages on the emotion of shame (405-509); see also the brief summary of some of the findings of this book in Ulrike Steinert, “'Zwei Drittel Gott, ein Drittel Mensch': Überlegungen zum altmesopotamischen Menschenbild," in Janowski, Der Ganze Mensch, especially 7074.

7 Cf., for example, David Konstan, The Emotions of the Ancient Greeks: Studies in Aristotle and Classical Literature (Toronto: University of Toronto Press, 2006) and the recent volume edited by John T. Fitzgerald, Passions and Moral Progress in Greco-Roman Thought (London: Routledge, 2007).

8 See the recent article by Wolfgang Zwickel, "The Iconography of Emotions in the Ancient Near East and in Ancient Egypt," in Egger-Wenzel and Corley, Emotions from Ben Sira to Paul, 1-25. In the same vein mention could be made of two earlier studies: Hellmuth Müller, "Darstellungen von Gebärden auf Denkmälern des Alten Reiches," MDAIK 7 (1937): 57-119 and Marcelle Werbrouck, Les Pleureuses dans L'Égypte ancienne (Bruxelles: Éditions de la Fondation Égyptologique Reine Élisabeth, 1938). 
There seem to be two possible ways in which people might try to communicate the quality of an emotional state. First, a speaker might use literal language to describe the events that triggered the emotional state ... In such a case, the literal description would not describe the quality of the subjective state itself but would merely identify its eliciting conditions . . . Alternatively, a speaker might use a metaphor in an attempt to describe the quality of an emotional state. For example, one might say that one felt as though one's insides were a butter churn. Here, the metaphorical description does represent an attempt to characterize the quality of a subjective state. ${ }^{9}$

Given that it is virtually impossible to encapsulate the true nature of an emotional state, one can perfectly understand why the writer of Lamentations (2:11) rather takes recourse to metaphorical discourse to convey the profundity of the experience of grief. A literal description would just not have been sufficiently intense to serve this specific purpose:

My eyes are worn from tears, my guts are in ferment, my liver/innards are poured out on the ground, over the destruction of the daughter of my people ... ${ }^{10}$

The same applies to the many emotional outbursts in the Psalms. There too the physiological and psychical components of, for example, an experience of distress are so intertwined that a proper decoding of emotion terminology is almost impossible. ${ }^{11}$ Barth is correct in claiming:

Die poetische Sprache der Psalmen bringt es mit sich, dass nur in wenigen Fällen Bestimmtes über die vorausgesetzte Situation gesagt werden kann. Oft werden Ausdrücke für eine Bedrängnis auf andere übertragen; oft scheint die Tendenz zu bestehen, ein begrenztes Leiden durch Anhäufung ganz verschiedenartiger Symptome zu totalisieren ... ${ }^{12}$

\footnotetext{
9 Andrew Ortony and Lynn Fainsilber, "The Role of Metaphors in Descriptions of Emotions," in Theoretical Issues in Natural Language Processing (ed. Yorick Wilks; Hillsdale, N.J.: Erlbaum, 1989), 181-182.

${ }^{10}$ For the translation, cf. Mark S. Smith, "The Heart and the Innards in Israelite Emotional Expressions: Notes from Anthropology and Psychobiology," JBL 117/3 (1998): 427.

11 See also the following statement by Risto Lauha, Emotionen (vol. 1 of Psychophysischer Sprachgebrauch im Alten Testament: Eine strukturalsemantische Analyse von רוח und נפש AASF 35; Helsinki: Suomalainen Tiedeakatemia, 1983), 125: "Tatsächlich sind das Psychische und das Physische, die Wirklichkeit und das Bild, oft miteinander zu einem untrennbaren Ganzen verschlungen."

12 Christoph Barth, Die Errettung vom Tode in den individuellen Klage- und Dankliedern des Alten Testaments (2nd ed.; Zürich: Theologischer Verlag, 1987), 93.
} 
However, where does one then start investigating such a multifaceted theme in the HB? Some would start from an etymological point of departure in an attempt to understand what is in fact signalled by the designation "emotion." But in such a case the danger lurks that our view of the term "emotion" is shaped in terms of our own language peculiarities. ${ }^{13}$ Furthermore, when consulting an English etymological dictionary such as Word Origins: the Hidden Histories of English Words from A to Z (2008), it appears that the word "emotion" is fairly recent (16th century). Semantically it denotes the following:

The semantic notion underlying emotion - of applying "physical movement" metaphorically to "strong feeling" - is an ancient one: Latin used the phrase mōtus animā, literally "movement of the spirit," in this sense. Emotion itself is a post-classical Latin formation; it comes ultimately from Vulgar Latin *exmovēre, literally "move out," hence "excite," ...

In view of this definition it is interesting to note that the Egyptologist, Altenmüller, in her survey on the nature of emotions in Egyptian culture opts for a similar term "Gefühlsbewegungen" to bring this nuance of "physical movement" - "strong feeling" to the fore. This is significant, since until very recently in HB studies, for example, there was no need to define the designation "emotion"; it was apparently obvious what this label refers to. Therefore one searches in vain in earlier studies on "emotions" like those of Johnson (1949),

13 Anna Wierzbicka, Emotions Across Languages and Cultures: Diversity and Universals (Cambridge: University Press, 1999), 2.

14 John Ayto, "Emotion," in Word Origins: the Hidden Histories of English Words from A to $Z$ (London: A \& C Black, 2008), n.p. [cited 28 May 2015]. Online: http://search.credoreference.com/content/entry/acbwordorig/emotion/.

15 Brigitte Altenmüller, "Gefühlsbewegungen," in vol. 2 of Lexikon der Ägyptologie (ed. Wolfgang Helck and Eberhard Otto; Wiesbaden: Harrassowitz, 1977), 508-510. Cf. also the title of the German translation of my English article, Paul A. Kruger, "On Emotions and the Expression of Emotions in the Old Testament: A Few Introductory Remarks," BZ 48/2 (2004): 213-228 as: "Gefühle und Gefühlsäusserungen im Alten Testament: Einige einführende Bemerkungen," in Der Mensch im Alten Testament: Neue Forschungen zur alttestamentlichen Anthropologie (ed. Bernd Janowski and Kathrin Liess; HBS 59; Freiburg: Herder, 2009, 243-262), and the remark by Wierzbicka, Emotions Across, 3: “. . . in ordinary German there is no word for 'emotion' at all. The word usually used as the translation equivalent of the English emotion, Gefühl . . . makes no distinction between mental and physical feelings, although contemporary scientific German uses increasingly the word Emotion, borrowed from scientific English, while in older academic German the compound Gemütsbewegung . it was often used in a similar sense." Italics in original.

16 Aubrey R. Johnson, The Vitality of the Individual in the Thought of Ancient Israel (Cardiff: University of Wales Press, 1949). 
Kruger, "Emotions in the Hebrew Bible," OTE 28/2 (2015): 395-420

Wolff (1973), ${ }^{17}$ or more recently Lauha (1983), ${ }^{18}$ to find some kind of definition. The first attempt by a biblical scholar to put a proposal on the table as point of departure is by Kruger. ${ }^{19}$

What is more, it appears that defining the concept "emotion" is a rather complicated enterprise; it is not just a "feeling." Add to this the fact that the term "emotion" is not present in all the languages of the world:

Languages all seem to have a word translatable as "feelings," but this is a more general term that subsumes sensations, drives, moods, and pains along with emotions. The idea that there is a certain class of feelings, the emotions, that constitutes a coherent domain of inquiry is not codified in every language. Indeed the word "emotion" was only introduced in English at the end of the sixteenth century. ${ }^{20}$

According to current social scientific studies, an emotion episode could include a number of components: "There are thoughts, bodily changes, action tendencies, modulations of mental processes such as attention, and conscious feelings. But which of these things is emotion?"21 One possibility would be to argue that the most characteristic element of an emotion is its "bodily appraisal" and to claim that "all emotions potentially occur with feelings of bodily changes." 22 However, some emotions, such as jealousy or guilt, are not necessarily accompanied by any characteristic physiological expressions. ${ }^{23}$ In the case of an emotion such as anxiety/distress, again, no specific cause can be identified as triggering that emotion. ${ }^{24}$ The fact remains that any scholar today who intends to investigate any given corpus of emotions or emotion language needs a wide array of competencies (linguistic, social, anthropological, psychological, philosophical, religious, etc.) to make sense of this phenomenon:

The ideal scholar in this area would therefore be well acquainted with findings from various fields, from biophilosophy . . . to neurobiology ... personal theory ... developmental psychology and psy-

17 Hans Walter Wolff, Anthropologie des Alten Testaments (München: Kaiser Verlag, 1973).

18 Lauha, Emotionen.

19 Kruger, "On Emotions and the Expression," 216; see also Andreas Wagner, "Gefühl, Emotion und Affekt in der Sprachanalyse des Hebräischen," in Emotionen, Gefühle und Sprache: Vier Studien (ed. Andreas Wagner; KUSATU 7; Waltrop: H. Spenner, 2006), 7-47, who makes a distinction between feeling, emotion and affect.

20 Jesse J. Prinz, Gut Reactions: A Perceptual Theory of Emotion (Oxford: Oxford University Press, 2004), 79; see also Wierzbicka, Emotions Across, especially Chapter 1.

21 Prinz, Gut Reactions, 3; italics in original.

22 Prinz, Gut Reactions, 91.

23 Konstan, Emotions, 27.

24 Konstan, Emotions, 27. 
chiatry ... political science and international relations . . . law and philosophy . . . cognitive linguistics . . . history . . . sociology and evolutionary psychology . . . and the humanities and cultural studies . . . ${ }^{25}$

Another controversial issue which has been prominent in emotion studies right from the beginning is the number of basic emotions identifiable. For example, in 1971 Izard $^{26}$ wrote that there are ten basic emotions: anger, contempt, disgust, distress, fear, guilt, interest, joy, shame, and surprise. In 1999 Ekman added some more items to this list and eventually came up with fifteen basic emotions: amusement, anger, contempt, contentment, disgust, embarrassment, excitement, fear, guilt, pride in achievement, relief, sadness/distress, satisfaction, sensory pleasure and shame. ${ }^{27}$ Noteworthy is the absence of emotions such as love and hate, which Ekman explains as "emotional plots, more specific, more enduring than the basic emotions . ..,28

Up to now the issue of how many basic emotions could be distinguished in an ANE text such as the HB has not been addressed. In a recent popular publication Schroer and Staubli start their article with the following general claim, without any further substantiation:

Die zehn heute als klassisch angesehenen, kulturübergreifenden Emotionen - Interesse, Leid, Widerwillen, Freude, Zorn, Überraschung, Scham, Furcht, Verachtung und Schuldgefühl ... werden auch in altorientalischen Texten beschrieben. ${ }^{29}$

But back to the term "emotion" as it applies to the HB. In view of what has been observed above about the history of the word "emotion," it is obvious that this designation ("emotion") could not have been used in that context. One way of expressing the presence of this notion was to employ the label נפש ("feeling"?), as was done in Exod 23:9: "You shall not oppress a foreigner, since you yourself know the feelings (נפש) of a foreigner, for you were foreigners in the land of Egypt." ${ }^{30}$ However, a search for the translation

25 James M. Wilce, Language and Emotion (Cambridge: Cambridge University Press, 2009), 28; emphasis in original.

26 Carroll E. Izard, The Face of Emotion (New York: Appleton-Century-Crofts, 1971).

27 Paul Ekman, "Basic Emotions," in The Handbook of Cognition and Emotion (ed. Tim Dagleish and Mick Power; New York: Wiley, 1999), 55.

28 Ekman, "Basic Emotions," 55; italics in original.

29 Schroer and Staubli, "Biblische," 44.

30 The translation is by Johnson, The Vitality, 14; see also Wolff's remark on this passage in Wolff, Anthropologie, 35: "Denn es nicht nur an die Bedürfnisse und Wünsche des Fremden gedacht, sondern an die ganze Skala seiner Empfindungen . .." Interestingly enough also to animals in the biblical world some kind of "feeling" is 
Kruger, "Emotions in the Hebrew Bible," OTE 28/2 (2015): 395-420

equivalent "Gefühle" (feeling) ${ }^{31}$ in a literal translation of the HB such as Die Elberfelder Bibel yields only one passage: "Mein Geliebter streckte seine Hand durch die Öffnung, da wurden meine Gefühle (מעים; PAK) für ihn erregt" (The Song of Songs 5:4). It is known that the "inner parts" (מעים) of the body are frequently associated with different "emotional" states (e.g., Isa 16:11; 63:15; Jer 4:19; 31:20; Ps 22:14; Job 30:27; Lam 1:20; 2:11). What is significant, however, in these descriptions is something that has not been taken seriously enough in the past, namely the register of lexical terms associated with these "emotion" scenarios and the nuances of meaning they most probably suggest. Such associative terms could perhaps provide a better idea of how emotions/feelings were conceptualised in ancient times. I will come back to this aspect later.

A few observations will be made below on some issues central to the present debate on emotions in the HB. These aspects are: (1) the limitations of the original psychophysical approach; (2) the cognitive approach and the question of a dominant conceptual metaphor; (3) the social-constructionist view of emotions and translation issues, and (4) a few brief comment on gender and emotions.

\section{B THE TRADITIONAL MIND - BODY PARADIGM AND THE PSYCHOPHYSICAL APPROACH}

In summarising the basic idea in the HB that humankind is a "psycho-physical organism," Johnson claims that "the various members and secretions of the body, such as the bones, the heart, the bowels, and the kidneys, as well as the flesh and blood, can all be thought of as revealing psychic properties." 32 Wolff some 20 years later still operates with a similar "synthesising" notion when speaking of the "Stereometrie des Gedankenausdrucks:",33

So setzt das stereometrische Denken zugleich eine Zusammenschau der Glieder und Organe des menschlichen Leibes mit ihren Fähigkeiten und Tätigkeiten voraus. Es ist synthetische Denken, das mit der Nennung eines Körperteils dessen Funktion meint. ${ }^{34}$

The intimate soul-body connection, however, had already been emphasised many years earlier by Pedersen, who held that

assigned: "The righteous knows the feelings (נפש) of his animals, but the compassion (רחמים) of the wicked is cruel" (Prov 12:10).

31 But even the term "feeling" is problematic according to Prinz, Gut Reactions, 79, since "this is a more general term that subsumes sensations, drives, moods and pains along with emotions."

32 Johnson, The Vitality, 88.

33 Wolff, Anthropologie, 22; italics in the original.

34 Wolff, Anthropologie, 23; italics in the original. 
The bodily sensations are felt right through the soul. . . . The feelings are like a gnawing anxiety in the bowels. The bowels . . . roar like waves in violent motion, whether for terror ... or pity ... or anger ... . They (the bowels: PAK) 'ferment'. . . or 'boil' . . . with the person in despair. ${ }^{35}$

Johnson (1949), though, was the first to connect metaphorical references to body parts and the physiological changes brought about by the experiencing of certain emotions. He refers, for instance, to metonymy in the case of the term א, which he claims "has the primary meaning of 'nostril,' but is used secondarily and more frequently of that quick nasal breathing or explosive snort which is indicative of anger." 36 Elsewhere (with regard to Judg 8:3) he makes use of this conceptual metaphor to link an abstract domain ("the calming down of anger") with a more concrete domain (a phenomenon in nature). The passage recounts Gideon's successful attempt to soothe the angry feelings of the Ephraimites, which led to "their anger (רוחם) subsiding (רפה)." Regarding the latter statement, Johnson remarks: "their רוח 'sank' רפה) just as we say of a wind that it sinks or dies down."37

Lauha, a few years later (1983), ${ }^{38}$ focused on the body parts לב , נפש and רוח in classifying different emotional experiences. He typifies these components as "psychophysical lexemes," which describe both the psychic and physical qualities of humans. With the help of a semantic field analysis he draws up a comprehensive list of concepts and their associative terms in order to determine how they are linguistically used to express the emotions of joy, sorrow, courage, fear, pride, humility, love and hatred. "However, since he was primarily interested in the semantics of לב רוח , לב and, he showed little interest in the possible conceptual content that these might have had." 39 Occasionally, however, he makes useful remarks on the metaphorical conceptions of particular emotions. For instance, when analysing words belonging to the same semantic field as sadness/grief/anxiety - such as מרר and, which basically denote "to be bitter" and "to be sour," respectively - he asserts that although these terms are primarily at home in a context of taste, they could likewise depict "andersartige Wahrnehmungen .. . die durch physische Schmerzen oder psychische Faktoren und Erfahrungen veranlasst sind . . . So wird z.B. der Stamm מרר hauptsächlich zur Schilderung von Gefühlen verwendet." ${ }^{\text {"Refer- }}$ צרר ring to two other terms which belong to the same semantic field, namely

35 Johannes Pedersen, Israel, Its Life and Culture (vol. 1-2; London: Oxford University Press, 1943 [1926]), 173; italics in the original.

36 Johnson, The Vitality, 11; see also Zacharias Kotzé, "A Cognitive Linguistic Approach to the Emotion of Anger in the Hebrew Bible," HTS 60/3 (2004): 851.

37 Johnson, The Vitality, 29.

38 Lauha, Emotionen.

39 Kotzé, "Cognitive Linguistic," 854.

40 Lauha, Emotionen, 114. 
Kruger, "Emotions in the Hebrew Bible," OTE 28/2 (2015): 395-420

("to restrict"/"to bind") and (צto constrain"), he states: "Trauer und Betrübtheit können auch beängstigend sein. Die Stämme צרר und צezeichnen Enge und damit eng verbundene Angst und Bedrängt-Sein." "41 Unfortunately he does not explore these conceptual ideas further. In general, he is most sceptical about the significance of the metaphors and metonymies associated with these emotion scenarios. In summarising the results of his study, he concludes:

Wenn Metapher und Metonymie in der Prosa und zumal in der Alltagsprache vorkommen, sind sie meistens schon verblasste Sprachbilder. Sie sind "tot" und sind in dem Masse zu regelmässigen Teilen der Sprache geworden, dass der Sprachteilhaber aufgehört hat, sie sich als Metaphern oder Metonyme vorzustellen. ${ }^{42}$

But it is precisely these "verblasste Sprachbilder" that became the focus of attention in the cognitive linguistic approach where this type of metaphoric speech is not deemed as insignificant, but as an essential "window to the mind."

\section{THE COGNITIVE APPROACH AND THE ISSUE OF A DOMINANT CONCEPTUAL METAPHOR}

The "conceptual turn" in the worldwide study of emotions is a recent phenomenon. The first cognitive linguists to link the body and emotions are Lakoff and Johnson (1980). ${ }^{43}$ They proceed from the basic notion of the universality of the language of emotion. ${ }^{44}$ They argue that "our ordinary conceptual system is metaphorical in nature." 45 Furthermore, these metaphors are not arbitrary: "They have a basis in our physical and cultural experience." 46 With regard to the emotion of joy, for example, they claim that the orientational metaphors HAPPY IS UP; SAD IS DOWN have their basis in what we experience physically and culturally. ${ }^{47}$ It is interesting to note, however, that many years earlier (1932) Vorwahl, ${ }^{48}$ in one of the first attempts to make conceptual sense of emo-

41 Lauha, Emotionen; my italics.

42 Lauha, Emotionen, 241.

43 See the seminal study by George Lakoff and Mark Johnson, Metaphors We Live By (Chicago: University of Chicago Press, 1980).

44 For criticism of Lakoff-Kövecses's paradigm, which advocates-essential similarities in universal human physiology, compare the viewpoint of scholars who recognise a phenomenon that may be called "local biologies." It operates with the notion of the uniqueness or specificity of cultural metaphors; see, e.g. Wilce, Language, 41.

45 Lakoff and Johnson, Metaphors, 4.

46 Lakoff and Johnson, Metaphors, 14.

47 Lakoff and Johnson, Metaphors, 14.

48 Heinrich Vorwahl, Die Gebärdensprache im Alten Testament (Berlin: Dr. Emil Ebering, 1932). 
tion language in the $\mathrm{HB}$, had already appealed to orientational metaphors in his understanding of a "positive" emotion such as joy and a "negative" emotion such as depression: the emotion of joy is UP, whilst depression/sadness is typically characterised by a DOWNWARD movement. With regard to joy, he claims:

Nach Klages sind die Ausdrucksbewegungen der Freude durch die Richtung nach oben beherrscht. Das gehobene Ich-gefühl geht auf Vergrösserung, worauf die Mittelpunktsflüchtigkeit der Bewegungen beruht. Darum heisst es in einem beliebten Bilde: "Du liessest mein Horn hoch erhoben sein."

Depression, on the other hand, he holds, is characterised "durch den Zug nach abwärts ...",50

Other recent studies also illustrate convincingly that orientational/spatial metaphors elsewhere in the HB are equally helpful in terms of which emotion imagery, especially that describing distressful situations, could be conceptualised. Compare, for example, the recent study by King, ${ }^{51}$ who investigates the most important image schemas and primary metaphors portraying distress in classical Hebrew. One of the conceptual metaphors he identified as best expressive of this type of imagery is the image schema verticality. Another recent example, conducted along similar lines, is an article by Eidevall that focuses on spatial metaphors in Lam 3:1-9. He persuasively maintains that width/confinement metaphors ("imprisoned/encircled/besieged") play a fundamental role in depicting extreme distress in that passage. ${ }^{52}$

Another conceptual metaphor Lakoff and Johnson suggest in terms of which experience, and specifically emotional experience, is structured, is container metaphors. In this respect one of the body parts most often associated with emotional states are the eyes, producing a conceptual metaphor such as: THE EYES ARE THE CONTAINERS OF THE EMOTIONS:

I could see the fear in his eyes. His eyes were filled with anger. There was passion in her eyes. His eyes displayed his compassion.

\footnotetext{
49 Vorwahl, Gebärdensprache, 9; my italics.

50 Vorwahl, Gebärdensprache, 14; my italics.

51 Philip D. King, Surrounded by Bitterness: Image Schemas and Metaphors for Conceptualizing Distress in Classical Hebrew (Eugene, Oreg.: Pickwick Publications, 2012).

52 Göran Eidevall, "Spatial Metaphors in Lamentations 3,1-9," in Metaphor in the Hebrew Bible (ed. Pierre van Hecke; Leuven: Leuven University Press, 2005), 133137.
} 
Kruger, "Emotions in the Hebrew Bible," OTE 28/2 (2015): 395-420

She couldn't get the fear out of her eyes. Love showed in his eyes. Her eyes welled with emotion. ${ }^{53}$

After analysing a representative example of anger scenarios in the HB, Kruger found that the same dominant metaphor likewise applies to the conceptualisation of anger: ANGER IS FLUID IN A CONTAINER ${ }^{54}$ Interestingly enough a similar conceptual metaphor is also encountered in other ANE literary texts. Compare, for example, the following Sumerian proverb describing the distinctive qualities of a leader, one of which is to "control anger like fluid in a container": "Fliesst das Herz über, (ist es ein) Jammer. Wer (es) im Herzen behält, (der ist) ein Prinz." age/contain" emotions is of essential importance. ${ }^{56}$

The appeal to the container metaphor in attempting to make conceptual sense of certain emotion scenarios, has, however, lately come in for some criticism. According to Wagner, such imagery is rather typical of the later GreekWestern world, where one often encounters references such as "I am full of love/hate." ${ }^{, 57}$ In the HB, according to Wagner, this conception is not significant at all:

Im Alten Testament findet sich die Behältermetapher so gut wie nicht. Gefühle erscheinen hier als etwas, das (von aussen) über den Menschen kommt . . . Für Gefühle und Emotionen gibt es plausible Gründe; man kann sich ihnen "naturgemäss" kaum entziehen und viel weniger eine "innere Kontrolle" ausüben, weil sie ja auch nicht als im Innern des Körpergefässes entstehend gedacht werden. ${ }^{58}$

53 Lakoff and Johnson, Metaphors, 50; italics in original. See also Paul A. Kruger, "The Face and Emotions in the Hebrew Bible," OTE 18/3 (2005): 651-663.

54 Paul A. Kruger, "A Cognitive Interpretation of the Emotion of Anger in the Hebrew Bible," JNSL 26/1 (2000): 181-193.

55 Steinert, Aspekte, 113.

56 See Christine Roy Yoder, "The Object of Our Affections: Emotions and the Moral Life in Proverbs 1-9," in Shaking Heaven and Earth: Essays in Honor of Walter Brueggemann and Charles B. Cousar (ed. Christine Roy Yoder, et al.; Louisvale: Westminster John Knox Press, 2005), 73-88.

57 For a recent summary of his viewpoints, see Andreas Wagner, "Emotionen in alttestamentlicher und verwandter Literatur - Grundüberlegungen am Beispiel des Zorns," in Egger-Wenzel and Corley, Emotions, 27-68.

58 Andreas Wagner, "Mensch (AT)," Das wissenschaftliche Bibellexikon in Internet (WiBiLex): Alttestamentlicher Teil, n.p. [cited 28 May 2015], (ed. Michaela Bauks and Klaus Koenen). Online: http://www.bibelwissenschaft.de/wibilex/dasbibellexikon/lexikon/sachwort/anzeigen/details/mensch-at-3/ch

/6ee365028ad1b3e6a07698ed3eb7147d/. See also Andreas Wagner, "Eifern und eifersüchtig sein: Zur sprachlichen Konzeptualisierung von Emotionen im Deutschen und Hebräischen," in Wagner, Emotionen, Gefühle und Sprache, 75-100. 
According to this view, emotions should rather be seen as forces "coming from the outside" taking control of a person, as is, for instance, reported in Num 5:14/30: "and the spirit of jealousy comes over (עבר על) him." Numbers 5:14/30 is, however, the sole passage in the HB where the combination עבר על ("to come over") is linked with an emotion, in this case jealousy. In order to make sense of this description, it is important to determine (1) which specific eventuality in real life often gives rise to this emotion, and (2) how it is conceptualised in the given passage. The triggering of jealousy in this context is attributed to a situation which may universally - and not only in the $\mathrm{HB}$ - be seen as one of the root causes of its activation, namely strife between husbands and wives: "Jealousy typically involves an attempt to protect a valued relationship (especially marriage) from a perceived threat (especially adultery). ${ }^{, 59}$ Such a situation could prompt certain feelings and actions, one of which may be the emotion of anger. ${ }^{60}$ Examples of such feelings and actions are also attested in the HB, for instance, Prov 6:34: "For jealousy (קנאה) (arouses) the fury (חמה) of a husband. He will show no mercy on the day of revenge."

But to return to the conceptual metaphor underlying the pronouncement in Num 5:14/30: "jealousy comes over him (עבר על)": if the combination על על "ע עבר is examined, it appears that it is mostly attested in a "spatial" sense, namely the "passing" from one geographical position to another. Applying this notion to the statement in Num 5:14/30 leads Wagner to argue that this passage provides clear evidence that the emotion of jealousy could here be seen as "external to the person" ("personenextern"). He defends this position as follows:

Klar ist dagegen, dass das Gefühl der Eifersucht als etwas von aussen Kommendes aufgefasst wird. Dieses Bild stellt damit typologisch gesehen, ohne polemischen Unterton - eine Art "Gegenbild," zur Behältermetapher dar ... ${ }^{61}$

However, in this context an alternative explanation is also likely, something Wagner himself hints at in maintaining "Sicher ist es zum einen so, dass damit die Unwiderstehlichkeit des Gefühls thematisiert werden soll . .."62 Indeed the phrase "to come over" has to do with an "external" element/force "coming over" a person, but there is an extra conceptual dimension attached to this metaphor, namely the reality that such an "external force" is so difficult or even impossible to resist/to keep in check that it just "overpowers/comes over someone like a raging torrent." It is precisely this shade of conceptual meaning

59 Gordon Clanton, "Jealousy and Envy," in Handbook of the Sociology of Emotions (ed. Jan E. Stets and Jonathan H. Turner; New York: Springer, 2006), 411.

60 Prinz, Gut Reactions, 30.

61 Wagner, "Emotionen in alttestamentlicher," 59; see also Wagner, "Eifern," 93.

62 Wagner, "Emotionen in alttestamentlicher," 59. 
Kruger, "Emotions in the Hebrew Bible," OTE 28/2 (2015): 395-420

("overpowering force") that is communicated by a comparable passage such as Ps 124:4, where the same semantic construction is employed (עבר על) in parallel to the idea "to be washed away" (שטף): "The waters would have washed us away (שטף); the torrent would have overwhelmed (עבר על) us." This implies that the root metaphor of the emotion of jealousy in Num 5:14/30 is not so much its trait as "personenextern," as Wagner claims, but that this description is rather another example of the conceptual metaphor: EMOTION IS A FORCE.

Furthermore, Wagner is correct in holding that, as far as the emotion jealousy (קנא) is concerned, no occurrence is found in the HB of the container metaphor. The same applies to hate (שנא), ${ }^{63}$ but he is not correct in his assertion: "Weitere Untersuchungen bleiben zwar noch abzuwarten, aber es scheint auch bei den meisten anderen Emotions- und Gefühlswörtern so zu sein, dass die Behälter-/Gefässmetapher nicht bzw. kaum verwendet wird."64 Although Kruger was perhaps a bit too optimistic in believing in the dominance of the container metaphor in the conceptualisation of anger, ${ }^{65}$ a few passages in the HB relating to this emotion would be hard to make sense of, if some or other kind of container metaphor is not presupposed. In 2 Sam 11:20 one reads, for example, that "the anger (חמה) of the king rises (עלה)." If it is accepted that the root עלה in its basic meaning "die Bewegung nach oben bezeichnet,"66 what then is the conceptual metaphor underlying this statement, if not that of a "rising substance in some or other kind of container"? Furthermore, how should the conceptual image in Jer 15:17 be understood, if not along the same lines as the previous one: "Because of your hand I sat alone, since you filled (מלא) me with rage (זעם; a synonym for אף/חמה: 'anger')"? And what about another Jeremiah passage (10:10), where it is abundantly clear that the source of anger does not have its source "outside" the experiencing subject, but "within" the person him/herself: "Due to his wrath (קצף; another synonym for 'anger') the earth trembles. The nations cannot contain (כול) his rage (זעם)." It is exactly this same container metaphor underlying the pronouncement of the priest Amaziah in Amos 7:10, when he warns Israel: "The country cannot 'contain/endure' (כול) his (Amos': PAK) words." According to Baumann: "Hier ist das Land als ein grosses Gefäss vorgestellt, das durch die aufrührerischen Worte des Amos in Gefahr geraten ist, zu bersten . ..,67

What about a few other similar examples, further afield (from the Ugaritic and Akkadian languages), where the container metaphor likewise appears to be dominant in the conceptualisation of certain emotions? Compare, for

63 Wagner, "Eifern," 86.

64 Wagner, "Eifern," 86.

65 See Kruger, "A Cognitive Interpretation of the Emotion of Anger."

66 Hans F. Fuhs, "עלה," ThWAT 6: 85.

67 Arnulf Baumann, "כול" "כול" in ThWAT 4: 94. 
instance, the following passage from the Ba ${ }^{e} \mathrm{lu}$ Myth (KTU 13 II 25-27) describing the joy felt by ${ }^{~}$ Anatu when fighting and slaughtering warriors:

tg்dd. kbdh. bṣhq. Her liver shook with laughter,

yml'u. lbh. b̌smht. $\quad$ her heart was filled with joy,

kbd. 'nt. trsyt. the liver of Anatu with triumph. ${ }^{68}$

Nowhere in the HB, though, does one encounter the metaphoric expression that someone "is filled with (מלא/ml') joy." In this corpus the conceptual metaphor associated with this emotion is rather: JOY IS LIGHT: "The light of my face (אור פני) they could not cast down" (Job 29:24); "The light of the eyes (מאור עינים) brings joy to the heart" (Prov 15:30). ${ }^{69}$

But back to container metaphor, which is, as noted above, likewise encountered in the Mesopotamian world. Similar to the HB, someone could also be "filled" (malû) with anger, as becomes clear from Steinert's summary of the conceptual representations of this emotion in the Akkadian language:

Das Herz kann . . . vor Zorn „brennen“ (libbu/kabattu + hamātu), sich mit Zorn „füllen“ (malû) wie ein Gefäss. Hat sich der Zorn entladen, atmet das Innere erleichtert auf (libbu/kabattu + napāšsu), ist „gelöst“ (pašāru, pațāru) oder „beschwichtigt“ (nâhu) wie ein Sturm, der sich legt. ${ }^{70}$

The latter conceptual metaphor ("the allaying of anger") is reminiscent of the passage referred to above (Judg 8:3), where mention is made of the "subsiding (רפה) anger" of the Ephraimites against Gideon: "their (רוח) 'sank' (רפה) - just as we say of a wind that it sinks.",71

In view of these few random examples from the HB, Ugarit and Mesopotamia, it appears that Wagner's claim that the container metaphor is hardly used in the HB (and for that matter also in the neighbouring cultures of Ugarit and Mesopotamia, had he included them in his analysis), cannot be upheld. On the contrary, it would be almost impossible to make conceptual sense of espe-

68 Cf. Marjo Korpel, A Rift in the Clouds: Ugaritic and Hebrew Descriptions of the Divine (Münster: Ugarit-Verlag, 1990), 167.

69 In the same vein, see the colourful description of Dan̄̄'lu's experiencing of joy in the 'Aqhatu Legend (KTU 117 II 9-11): "Dan̄̄lu's face lit up with joy, his countenance glowed. Signs of worry disappeared from his forehead, as he laughed, he (relaxed as he) put his feet on the footstool." The translation is by Dennis Pardee, "The 'Aqhatu Legend," in The Context of Scripture (vol. 1; ed. William W. Hallo; Leiden: Brill, 2003), 345.

70 Steinert, "'Zwei Drittel Gott,", 73.

71 Johnson, The Vitality, 29. 
Kruger, "Emotions in the Hebrew Bible," OTE 28/2 (2015): 395-420

cially the emotions of anger, and to a lesser degree also that of joy, if the container metaphor is not presupposed in some or other form.

Elsewhere in the HB other conceptual metaphors present themselves as similarly fundamental in the metaphorical expressions of emotions. For example, if one undertakes a conceptual analysis of the emotion of fear in the HB, it emerges that one of the most productive metaphors is: FEAR IS AN ENEMY/OPPONENT. It provides the basis for the following entailments:

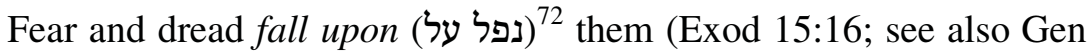
15:12; Josh 2:9; Ps 55:5; Job 13:11).

Agony grips (חז, hip $\left.{ }^{\mathrm{il}}\right)^{73}$ us, anguish like a woman in labour (Jer 6:24; see also 49:24; 50:43; Mic 4:9).

When distress and anguish come upon (בוא על) you (Prov 1:27).

In Akkadian literature, likewise, a similar ENEMY/OPPONENT metaphor is utilised for the conceptualisation of the same emotion. Compare the following description in the annals of Sennacherib when fear (puluhtu) takes possession of the adversary:

As for the king of Babylon and the king of Elam, the chilling terror of my battle overcame ( $\operatorname{sah} \bar{a} p u^{75}:$ PAK) them, they let their dung go into their chariots, they ran off alone. ${ }^{76}$

Other related examples in the Akkadian language for conceptualisations of fear (puluhtu) include that it can "go into" (erēbu $)^{77}$ the heart/body like a

72 For נפל על in a military context, cf. Jer 48:32 and Paul A. Kruger, "A Cognitive Interpretation of the Emotion of Fear in the Hebrew Bible," JNSL 27/2 (2001): 86.

73 For חז ח (hip il) in a hostile context, see Dan 11:21.

74 For in a context of enmity, see e.g. Gen 34:27.

75 For sahāpu in the sense of evil powers or demons "overtaking/overcoming" someone, cf. CAD sahāpu 1e, 33. See also Steinert, Aspekte, 246.

76 Lines 53-54; the translation is by Daniel D. Luckenbill, The Annals of Sennacherib (Chicago: The University of Chicago Press, 1924), 89. The latter pronouncement is in line with one of the metonymies associated with the experiencing of the fear emotion elsewhere, viz. "the involuntary release of bowels and bladder." Cf. the following cases in the HB and the apocryphal literature, respectively: "When it comes, every heart will melt and all hands will grow weak. Every spirit will faint and every man will wet himself" (lit. "all knees will run with water," ברכים הלך מים; Ezek 21:12; for the translation, see Dilbert R. Hillers, "A Convention in Hebrew Literature: The Reaction to Bad News," ZAW 77 (1965): 88; “(Then) a great trembling and fear seized me and my loins and kidneys lost control" (1 En 60:3; the translation is by Ephraim Isaac, "1 Enoch," in The Old Testament Pseudepigrapha (vol. 1; ed. James H. Charlesworth; New York: Doubleday, 1983), 40; see also Kruger, "A Cognitive Interpretation of the Emotion of Fear," 84, for more examples. 
disease, that it can "fall upon" $\left(\right.$ maqātu $\left.{ }^{78}\right)$ a person, or that it can be "poured over" (tabāku) someone. ${ }^{79}$

In the case of depression, again, it emerges that the principal orientational/spatial metaphor is: DEPRESSION IS DOWN. We often read of the typical "downward posture" of depressive persons in the HB, especially in the Psalms: "I wandered about as one who laments for a mother, I was gloomy (and) bowed down"(שחח; Ps. 35:14); "I am utterly bowed down and prostrate (שחח), all day long I go around gloomy" (Ps 38:7).

Similarly, Akkadian literature bears evidence of several instances of this "downward posture" of the body in the state of sadness/depression. Babylonian wisdom poem Ludlul bèl nèmeqi, Shubshi-meshre-Shakkan, discovers that he has fallen into disfavour in public and private life, he reacts first and foremost in an emotional fashion expressive of depression. The text (Tablet 1, lines 7374) reports: "My proud head bowed to the ground, terror weakened my stout heart." ${ }^{81}$ In one of the Amarna letters (EA 7) comparable imagery is present. It tells about the Babylonian king Burra-Buriyaš complaining to the Egyptian king of the neglect by his relatives during his illness/depression ("head down") (Lines 14-17):

Als ich krank war (wörtl. mein Fleisch mir nicht wohl war), hat mein Bruder mi[ich nicht ermutigt (wörtl. mein Kopf nicht gehoben)]. Ich wurde voller Zorn gegenüber meinem Bruder (und sagte) wie folgt: "Als ich elend war, hat mich mein Bruder nicht (an)gehört. Warum hat er mich nicht getröstet (meinen Kopf nicht gehoben)?" 82

In another context a related orientational/spatial metaphor is utilised to signal a similar emotional condition, but this time associated with another body

77 For a similar conceptual metaphor FEAR AS AN ILLNESS, cf. Ps 55:6: "Fear and trembling entered into me" (בוא ב).

78 Cf., e.g. the following examples in Donald J. Wiseman, Chronicles of Chaldaean Kings (626-556 B.C.) in the British Museum (London: Trustees of the British Museum, 1956): "Fear of the enemy fell upon (maqātu; PAK) them" (Chron 62 r.62), or "Fear fell on (maqātu; PAK) the city" (52:18).

79 Steinert, Aspekte, 246.

${ }^{80}$ See Paul A. Kruger, "Depression in the Hebrew Bible: An Update," JNES (2005): 190.

81 The translation is by Amar Annus and Alan Lenzi, Ludlul bèl nēmeqi: The Standard Babylonian Poem of the Righteous Sufferer (SAACT 7; Helsinki: Neo-Assyrian Corpus Project, 2010), 33.

82 Steinert, Aspekte, 199. 
part, the heart. It is said that the heart "has fallen" (miqit libbi), or that it has been "lowered" (̌̌apālu) ${ }^{83}$

To sum up: it appears that there is no such thing as a dominant conceptual metaphor in the understanding of emotions. The type of metaphor to be employed in a given emotion scenario depends on the cultural conception of that specific feeling. For example, in the case of the conceptualisation of anger, as far as the HB is concerned, the container metaphor seems to be more pervasive than other conceptual metaphors. This differs with respect to an emotion such as fear, where other conceptual metaphors appear to be more prevalent, like: FEAR IS AN ENEMY/OPPONENT. In the expression of the emotions of joy and sadness/depression, again, it emerges that orientational metaphors (HAPPY IS UP; SAD IS DOWN) are predominant.

\section{THE SOCIAL-CONSTRUCTIONIST VIEW OF EMOTIONS AND TRANSLATION ISSUES}

In a recent volume on philosophical theories about the emotions, the following instructive remark is made in the introduction:

Gefühle hatten Menschen schon immer . . . Differenzen - und damit verbunden: die Notwendigkeit von Differenzierungen - setzen indes dort ein, wo sich die Frage stellt, welche Emotionen Menschen genau haben und wie man diese unterscheiden, beschreiben oder erklären will . . . Ist, was unsere Alltagssprache suggeriert, Eifersucht fast dasselbe wie Neid . . . Ist das Phänomen der Angst von dem der Furcht verschieden . . . Ergreift uns heute immer noch Melancholie, oder leiden wir schlicht unter depressiven Verstimmungen? Es stellt sich die Frage, ob die Menschen vergangener Epochen Anderes fühlten oder ob es sich hier um blosse Übersetzungsprobleme handelt. ${ }^{84}$

Or to put it slightly differently, in the words of the anthropologist Lutz, who holds that "emotional meaning is fundamentally structured by particular cultural systems and particular social and material environments. . . emotional experience is not precultural but preeminently cultural." 85 If adopting this social-constructionist angle as point of departure, it is furthermore true that

The process of coming to understand the emotional lives of people in different cultures can be seen first and foremost as a problem of

83 Steinert, "“Zwei Drittel Gott,"” 73.

84 Hilge Landweer and Ursula Renz, "Zur Geschichte philosophischer Emotionstheorien," in Handbuch Klassischer Emotionstheorien: Von Plato bis Wittgenstein (ed. Hilge Landweer and Ursula Renz; Berlin: De Gruyter, 2012), 3.

85 Catherine A. Lutz, Unnatural Emotions: Everyday Sentiments on a Micronesian Atoll and Their Challenge to Western Theory (Chicago: University of Chicago, 1988), 5; emphasis in the original. 
translation . . The interpretive task, then, is . . to translate emotional communications from one idiom, context, language, or sociohistorical mode of understanding into another. ${ }^{86}$

However, in a "dead" language such as that of the HB, such a "translation" enterprise is extremely complicated. The linguistic equivalents that translators had at their disposal in "decoding" given emotion words or emotion experiences were dependent on the lexical items available at that point in time. For example, in the case of the earliest translation of the HB, the LXX, it is natural to expect that the translation equivalents of certain emotion words would have been coloured by the cultural conventions deemed appropriate at that specific historical period. As a random example, consider, for instance, the use of the Greek verb $\lambda u \pi \varepsilon \tilde{I} \nu$ and its noun form, $\lambda u ́ \pi \eta$, of which, according to Muraoka, the primary meanings are "to grieve, cause grief" and "grief, sadness," respectively. ${ }^{87}$ Occasionally, though, they are utilised in the LXX to render terms which in the MT primarily belong to the semantic domain of "anger": קצף (seven times: 1 Sam 29:4, 2 Kgs 13:19, Isa 57:17 (2x), Esth 1:12, 2:21 [all in the qal] and Isa 8:21 [in the hitpa 'el]), חרה (5x: Gen 4:5, Jonah 4:4, 4:9 [2x]), Neh 5:6 and רגז (2x: Isa 32:11, Ezek 16:43) ${ }^{88}$ This seems to correspond to the fact that the Greek $\lambda \dot{v} \pi \eta / \lambda \cup \pi \varepsilon i \tilde{v}$ covers a broader/different range of semantic nuances in comparison with Hebrew. In some contexts this Greek combination could even be employed to capture a feeling/emotion which in Hebrew would belong in the semantic domain of anger. ${ }^{89}$

One may continue along the same lines and refer to the emotion vocabularies available for the same emotion ("anger") in modern languages such as, for example, those in German and English. For the ten terms employed for

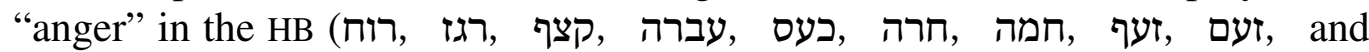
ףא), ${ }^{90}$ German Bible translations mostly opt for three lexical equivalents, viz.

86 Lutz, Unnatural Emotions, 8.

87 Takamitsu Muraoka, A Greek-English Lexicon of the Septuagint (Louvain: Peeters, 2009), 436.

88 Rudolf Bultmann, “ $\lambda u ́ \pi \eta / \lambda u \pi \varepsilon \tilde{\imath}$, ," TWNT 4: 319.

89 For this example, see Petra von Gemünden, "Methodische Überlegungen zur Historischen Psychologie exemplifiziert am Themenkomplex der Trauer in der Bibel und ihrer Umwelt," in Der Mensch im Alten Israel: Neue Forschungen zur alttestamentlichen Anthropologie (ed. Bernd Janowski and Kathrin Liess; HBS 59; Freiburg: Herder, 2009), 41-68.

90 See Bruce E. Baloian, Anger in the Old Testament (New York: Peter Lang, 1992), 5. The term used most often (210 times) is אף, which is connected with both divine and human anger. The verb derived from אנף, אף, is apparently only used for divine wrath; see Stefan H. Wälchli, Gottes Zorn in den Psalmen: Eine Studie zur Rede vom Zorn Gottes in den Psalmen im Kontext des Alten Testamentes und des Alten Orients (OBO 244; Fribourg: Academic Press, 2012), 29. The second most used term to des- 
Kruger, "Emotions in the Hebrew Bible," OTE 28/2 (2015): 395-420

"Zorn," "Wut" or "Ärger." To match these German terms in an English translation, the equivalent "anger" is mostly utilised. Yet none of these German words is a perfect counterpart for the English term "anger."91

The translation of the Hebrew root קנא may serve as another case in point. ${ }^{92}$ So one will find in English Bible translations, for example, that three terms, namely "zeal," "jealousy" and "envy," are usually opted for in an attempt to denote the different semantic variations of the one root (קנא) in Hebrew. According to Elliott, however, these three emotion terms ("zeal," "jealousy" and "envy") differ in Western thought with regard to the social situations giving rise to them, the social relations and the social dynamics:

Zeal marks the intensity of feeling one person or group has in regard to something or someone or some other group . . . Jealousy is intense feeling concerning one's possessions and rivalry with others ... Envy is an intense feeling like zeal and jealousy, and, like jealousy, concerns the possession of someone or something, but has no positive quality. ${ }^{93}$

A literal German translation, such as Die Elberfelder Bibel, in the majority of occurrences of the different variations of קנא, chooses "eifern/eifersüchtig" ("jealous"/ "jealousy") as a suitable translation equivalent. In a few cases, however, the counterpart "beneiden" ("to envy": Gen 26:14, Ezek 31;9, Ps 37:1, 73:3 and Prov 3:31) or "neidisch" ("envious": Prov 24:1) is suggested. In two cases (Prov 14:30, Song of Songs 8:6), though, the rendering "Leidenschaft" ("passion") is selected as the term best capturing the specific nuance of meaning in those contexts. Luther, on the other hand, prefers in 56 of the instances of the root קנא, the translation equivalent "Eifer" ("zeal"). קנאה While the Die Elberfelder Bibel in the case of Song of Songs 8:6 renders as Leidenschaft ("Denn stark wie der Tod ist die Liebe, hart wie der Scheol die Leidenschaft"), Luther translates: "Die Liebe ist stark wie der Tod, und der

ignate anger is חמה, which could be translated as "blazing anger" ("Zornesglut"); see Wälchli, Gottes Zorn, 49.

91 For the semantic differences between these terms in German and the corresponding terms in English for "anger," cf. Uwe Durst, "Why Germans Don't Feel 'Anger," in Emotions in Crosslinguistic Perspective (ed. Jean Harkins and Anna Wierzbicka; Berlin: De Gruyter, 2001), 115-148.

92 The verb occurs 34 times in the HB, the noun 43 times and the adjective 6 times; see John H. Elliott, "Envy, Jealousy, and Zeal in the Bible: Sorting out the Social Differences and Theological Implications - No Envy for YHWH," in To Break Every Yoke: Essays in Honor of Marvin L. Chaney (ed. Robert B. Coote and Norman K. Gottwald; Sheffield: Sheffield Phoenix Press, 2007), 344-364.

93 Elliott, "Envy," 345-346.

94 Karl-Heinz Bernhardt, Gott und Bild: Ein Beitrag zur Begründung und Deutung des Bildverbotes im Alten Testament (Berlin: Evangelische Verlagsanstalt, 1956), 89, note 3 . 
Eifer ist fest wie die Hölle." "95 Over and against Die Elberfelder Bibel where the translation equivalent "Eifersucht" often occurs to match some or other semantic shade of the root קנא, this concept is nowhere attested in Luther's translation. The reason may be that Luther, at that stage of the historical development of the German language, did not have the designation "Eifersucht" available, since this term dates from later times. ${ }^{96}$

\section{E GENDER AND EMOTIONS}

In a recent book entitled Gender Feelings ${ }^{97}$ the observation is made that in a modern world the concept "emotionality" invokes certain associations that are often attributed to either men or women. The attitudes emotional, sensitive and loving are associated with femaleness, whilst rational, aloof, insensitive, etcetera are associated with maleness. ${ }^{98}$ Earlier the anthropologist Lutz had expressed a similar sentiment by saying that in everyday terms "to be emotional" means not only to be "female," but also displaying a weakness that should be controlled:

As both an analytic and an everyday concept in the West, emotion, like the female, has typically been viewed as something natural rather than cultural, irrational rather than rational, chaotic rather than ordered, subjective rather than universal, physical rather than mental or intellectual, unintended and uncontrollable, and hence often dangerous. $^{99}$

Given this perception that "emotionality" is mostly associated with "femaleness," the question arises whether this is also applicable to HB evidence. Were certain forms of emotional behaviour, for example, less acceptable for women, due perhaps, to their social status? It is interesting to note that, apart from anger and perhaps love, it seems that the HB is predominantly "gender neutral." For instance, regarding the emotion displaying sadness, crying, which in a modern and also in the classical worlds is typically viewed as a female characteristic, the HB makes no distinction between the sexes: both males and females are reported to express this sentiment (for men crying, cf. Gen 45: 14-

95 Hildegard Baumgart, Eifersucht: Erfahrungen und Lösungsversuche im Beziehungsdreieck (Hamburg: Rowohlt, 1985), 96.

96 Baumgart, Eifersucht, 125-126.

97 Daniela Rippl and Verena Mayer, eds., Gender Feelings (München: Wilhelm Fink, 2008).

98 Daniela Rippl, “Gender Feelings - Emotion Trouble,” in Gender Feelings (ed. Daniela Rippl and Verena Mayer; München: Wilhelm Fink, 2008), 9.

99 Catherine A. Lutz, "Engendered Emotion: Gender, Power, and the Rhetoric of Emotional Control in American Discourse," in The Emotions: Social, Cultural and Biological Dimensions (ed. Rom Harré and W. Gerrod Parrott; London: Sage Publications, 1996), 151. 
Kruger, "Emotions in the Hebrew Bible," OTE 28/2 (2015): 395-420

15; 2 Sam 19:1-2; 2 Kgs 13:14; Job 2:12, etc). ${ }^{100}$ While mercy and compassion (רחמים) are connected in a terminological and metaphoric sense with the womb (רחם), the HB ascribes this emotion to both sexes: Joseph (Gen 43:30), as well as mothers (1 Kgs 3:26), could experience this emotion. ${ }^{101}$ However, with reference to the emotion of anger, no trace is found of women getting angry or of anger being directed against women. ${ }^{102}$ One reason could be, as Van Wolde claims: "The fact that anger is conceived as uncontrollable aggression addressed to some other person makes it probably an unsuitable characteristic for a woman." 103 Furthermore, it appears that also love (if it could count as an emotion), when it comes to the relationship between a man and a woman, especially in the patriarchal Israelite society, is expressed in terms of hierarchical positions. ${ }^{104}$ Several passages bear testimony to the fact that the man is the socially superior person in this relationship; he is the one taking the initiative (e.g., Gen 24:67; 29:18, 30; 34:3; Deut 21:15 (2x); Judg 14:16; 16:4, 15; 2 Sam $13: 1,4,15 ; 1 \mathrm{Kgs} 11: 1,2$, etc.). Apart from passages in the poetic books (e.g., Prov 5:19 and instances in Song of Songs, e.g., 2:5; 5:8), the sole instance in the narrative parts of the HB where mention is made of the "love" of a woman for a man is 1 Sam 18:20 (see also v. 28). Here it is said: "Michal, Saul's daughter, loved (אהב) him (= David)." Given the fact that she is the daughter of king, it is natural to suspect that "she takes on the hierarchically superior position in this relationship." 105 Furthermore, the nature of this love relationship between a man and a woman is likewise different from the cultural notion in contemporary Western civilisation. Whereas in the latter "love" is viewed as romantic and reciprocal, in the HB it is "the sentiment, attitude and behaviour of a man towards a woman.",106

\section{F CONCLUSION}

Although there has been considerable progress in recent years in the study of different facets of the emotions in the HB, a variety of aspects still need attention or serious reflection, of which the following may be the most important. (1) Very little has been done on what the term "emotion" exactly entails in the context of the HB. Closely connected with this matter is the question of the

100 See also Schroer and Staubli, "Biblische Emotionswelten," 46.

101 Christl M. Maier, "Körper und Geschlecht im Alten Testament: Überlegungen zur Geschlechterdifferenz, " in Menschenbilder und Körperkonzepte im Alten Israel, in Ägypten und im Alten Orient (ed. Angelika Berlejung, Jan Dietrich and Joachim Friedrich Quack; ORA 9; Tübingen: Mohr Siebeck, 2012), 200.

102 Klaus-Dietrich Schunck, "חמה," ThWAT 2: 1034.

103 Ellen van Wolde, "Sentiments as Culturally Constructed Emotions: Anger and Love in the Hebrew Bible," BibInt 16/1 (2008): 14.

104 Van Wolde, "Sentiments," 18-22.

105 See Tiana Bosman, "Biblical Hebrew Lexicology and Cognitive Semantics: A Study of Lexemes of Affection" (Ph.D. diss.; Stellenbosch University, 2011), 128.

106 Van Wolde,"Sentiments," 19. 
number of basic emotions that could be identified. (2) The recent advent of the cognitive turn in emotion studies poses several challenges for the study of emotions in the social sciences in general, and in the HB in particular. One of the basic aspects is how the notion of the universality of emotion language fundamental to this approach is to be reconciled with the social-constructionist principle, which depends on the view that cultural items are unique or cultural specific. This question is especially pertinent in the study of emotions in a "dead" language such as Biblical Hebrew, where the researcher has no other option but to rely on modern comparative social-scientific evidence in order to make sense of emotion language. (3) Another issue has a bearing on the translatability of emotion terms. In HB translations one usually encounters the tendency to shy away from the complexity of emotion vocabularies and to resort to stereotypical and traditional translation equivalents. Such linguistic choices need to be reconsidered and refined. (4) A last matter, of fairly recent date, relates to the theme of gender and emotions in the HB and also on this the last word has not yet been spoken.

\section{BIBLIOGRAPHY}

Altenmüller, Brigitte. "Gefühlsbewegungen.” Pages 508-510 in vol. 2 of Lexikon der Ägyptologie. Edited by Wolfgang Helck and Eberhard Otto. Wiesbaden: Harrassowitz, 1977.

Annus, Amar and Alan Lenzi. Ludlul bèl nèmeqi: the Standard Babylonian Poem of the Righteous Sufferer. State Archives of Assyria Cuneiform Texts 7. Helsinki: Neo-Assyrian Corpus Project, 2010.

Ayto, John. "Emotion." No Pages in Word Origins: the Hidden Histories of English Words from A to Z. London: A \& C Black, 2008. Cited 28 May 2015. Online: http://www.credoreference.com.ez.sun.ac.za/entry/acbwordorig/emotion.

Baloian, Bruce E. Anger in the Old Testament. New York: Peter Lang, 1992.

Barth, Christoph. Die Errettung vom Tode in den individuellen Klage- und Dankliedern des Alten Testaments. 2nd ed. Zürich: Theologischer Verlag, 1987.

Baumgart, Hildegard. Eifersucht: Erfahrungen und Lösungsversuche im Beziehungsdreieck. Hamburg: Rowohlt, 1985.

Bernhardt, Karl-Heinz. Gott und Bild: Ein Beitrag zur Begründung und Deutung des Bildverbotes im Alten Testament. Berlin: Evangelische Verlagsanstalt, 1956.

Bosman, Tiana. "Biblical Hebrew Lexicology and Cognitive Semantics: A Study of Lexemes of Affection." Ph.D. Dissertation. Stellenbosch University, 2011.

Clanton, Gordon. "Jealousy and Envy." Pages 410-442 in Handbook of the Sociology of Emotions. Edited by Jan E. Stets and Jonathan H. Turner. New York: Springer, 2006.

Durst, Uwe. "Why Germans Don't Feel 'Anger."” Pages 115-148 in Emotions in Crosslinguistic Perspective. Edited by Jean Harkins and Anna Wierzbicka. Berlin: De Gruyter, 2001.

Egger-Wenzel, Renate and Jeremy Corley. Emotions from Ben Sira to Paul. Deuterocanonical and Cognate Literature Yearbook. Berlin: De Gruyter, 2011. 
Kruger, "Emotions in the Hebrew Bible," OTE 28/2 (2015): 395-420

Eidevall, Göran. "Spatial Metaphors in Lamentations 3,1-9." Pages 133-137 in Metaphor in the Hebrew Bible. Edited by Pierre van Hecke. Leuven: Leuven University Press, 2005.

Elliott, John H. "Envy, Jealousy, and Zeal in the Bible: Sorting out the Social Differences and Theological Implications - No Envy for YHWH." Pages 344364 in To Break Every Yoke: Essays in Honor of Marvin L. Chaney. Edited by Robert B. Coote and Norman K. Gottwald. Sheffield: Sheffield Phoenix Press, 2007.

Ekman, Paul. "Basic Emotions." Pages 45-60 in The Handbook of Cognition and Emotion. Edited by Tim Dagleish and Mick Power. New York: Wiley, 1999.

Fitzgerald, John T. Passions and Moral Progress in Greco-Roman Thought. London: Routledge, 2007.

Frevel, Christian. Biblische Anthropologie: Neue Einsichten aus dem Alten Testament. Quaestiones Disputatae 237. Freiburg: Herder, 2010.

Greco, Monica and Paul Stenner. Emotions: A Social Science Reader. New York: Routledge, 2008.

Harding, Jennifer and E. Deidre Pribram. Emotions: A Cultural Studies Reader. New York: Routledge, 2009.

Hillers, Dilbert R. "A Convention in Hebrew Literature: the Reaction to Bad News." Zeitschrift für die alttestamentliche Wissenschaft 77 (1965): 86-90.

Isaac, Ephraim. "1 Enoch.” Pages 5-89 in vol. 1 of The Old Testament Pseudepigrapha. Edited by James H. Charlesworth. New York: Doubleday, 1983.

Izard, Carroll E. The Face of Emotion. New York: Appleton-Century-Crofts, 1971.

Janowski, Bernd. Der Ganze Mensch: Zur Anthropologie der Antike und ihrer europäischen Nachgeschichte. Berlin: Akademie Verlag, 2012.

Johnson, Aubrey R. The Vitality of the Individual in the Thought of Ancient Israel. Cardiff: University of Wales Press, 1949.

King, Philip D. Surrounded by Bitterness: Image Schemas and Metaphors for Conceptualizing Distress in Classical Hebrew. Eugene, Oreg.: Pickwick Publications, 2012.

Konstan, David. The Emotions of the Ancient Greeks: Studies in Aristotle and Classical Literature. Toronto: University of Toronto Press, 2006.

Korpel, Marjo C. A. A Rift in the Clouds: Ugaritic and Hebrew Descriptions of the Divine. Münster: Ugarit-Verlag, 1990.

Kotzé, Zacharias. "A Cognitive Linguistic Approach to the Emotion of Anger in the Hebrew Bible.” Hervormde Teologiese Studies 60/3 (2004): 843-863.

Kruger, Paul A. "A Cognitive Interpretation of the Emotion of Anger in the Hebrew Bible." Journal of Northwest Semitic Languages 26/1 (2000): 181-193. . "A Cognitive Interpretation of the Emotion of Fear in the Hebrew Bible." Journal of Northwest Semitic Languages 27/2 (2001): 77-89. . "On Emotions and the Expression of Emotions in the Old Testament: A Few Introductory Remarks." Biblische Zeitschrift 48/2 (2004): 213-228. . "The Face and Emotions in the Hebrew Bible." Old Testament Essays 18/3 (2005): 651-663. . "Depression in the Hebrew Bible: An Update." Journal of Near Eastern Studies (2005): 187-192. 
418 Kruger, "Emotions in the Hebrew Bible," OTE 28/2 (2015): 395-420

. "Gefühle und Gefühlsäusserungen im Alten Testament: Einige einführende

Bemerkungen." Pages 243-262 in Der Mensch im Alten Testament: Neue

Forschungen zur alttestamentlichen Anthropologie. Edited by Bernd Janowski and Kathrin Liess. Herder Biblische Studien 59. Freiburg: Herder, 2009.

Lakoff George and Mark Johnson. Metaphors We Live By. Chicago: University of Chicago Press, 1980.

Landweer, Hilge and Ursula Renz. "Zur Geschichte philosophischer Emotionstheorien." Pages 1-17 in Handbuch Klassischer Emotionstheorien: Von Plato bis Wittgenstein. Edited by Hilge Landweer and Ursula Renz. Berlin: De Gruyter, 2012.

Lauha, Risto. Emotionen. Volume 1 of Psychophysischer Sprachgebrauch im Alten Testament: Eine strukturalsemantische Analyse von רוח und נפש לב Annales Academiae Scientiarum Fennicae 35. Helsinki: Suomalainen Tiedeakatemia, 1983.

Luckenbill, Daniel D. The Annals of Sennacherib. Chicago: The University of Chicago Press, 1924.

Lutz, Catherine A. Unnatural Emotions: Everyday Sentiments on a Micronesian Atoll and Their Challenge to Western Theory. Chicago: University of Chicago Press, 1988.

. "Engendered Emotion: Gender, Power, and the Rhetoric of Emotional Control in American Discourse." Pages 151-170 in The Emotions: Social, Cultural and Biological Dimensions. Edited by Rom Harré and W. Gerrod Parrott. London: Sage Publications, 1996.

Maier, Christl M. "Körper und Geschlecht im Alten Testament: Überlegungen zur Geschlechterdifferenz." Pages 183-207 in Menschenbilder und Körperkonzepte im Alten Israel, in Ägypten und im Alten Orient. Edited by Angelika Berlejung, Jan Dietrich and Joachim Friedrich Quack. Orientalische Religionen in der Antike 9. Tübingen: Mohr Siebeck, 2012.

Milton, Kay and Maruška Svašek. Mixed Emotions: Anthropological Studies of Feeling. New York: Berg Publishers, 2005.

Müller, Hellmuth. "Darstellungen von Gebärden auf Denkmälern des Alten Reiches." Mitteilungen des Deutschen Archäologischen Instituts Kairo 7 (1937): 57-119.

Muraoka, Takamitsu. A Greek-English Lexicon of the Septuagint. Louvain: Peeters, 2009.

Ortony, Andrew and Lynn Fainsilber. "The Role of Metaphors in Descriptions of Emotions." Pages 178-182 in Theoretical Issues in Natural Language Processing. Edited by Yorick Wilks. Hillsdale, N.J.: Erlbaum, 1989.

Pardee, Dennis. "The 'Aqhatu Legend." Pages 343-356 in vol. 1 of The Context of Scripture. Edited by William W. Hallo. Leiden: Brill, 2003.

Pedersen, Johannes. Israel, Its Life and Culture. Volumes 1-2. London: Oxford University Press, 1943 [1926].

Prinz, Jesse J. Gut Reactions: A Perceptual Theory of Emotion. Oxford: Oxford University Press, 2004.

Rippl, Daniela. "Gender Feelings - Emotion Trouble." Pages 9-25 in Gender Feelings. Edited by Daniela Rippl and Verena Mayer. München: Wilhelm Fink, 2008.

Rippl, Daniela and Verena Mayer, eds. Gender Feelings. München: Wilhelm Fink, 2008. 
Kruger, "Emotions in the Hebrew Bible," OTE 28/2 (2015): 395-420

Rueda, María Isabel Toro. "Das Herz in der ägyptischen Literatur des zweiten Jahrtausends v. Chr. Untersuchungen zu Idiomatik und Metaphorik von Ausdrücken mit jb und ḥ3tj.” Ph.D. diss., University of Göttingen, 2003. Cited 28 May 2015. Online: http://d-nb.info/972097295/34.

Schroer, Silvia and Thomas Staubli. "Emotionswelten." Kategetische Blätter 132/1 (2007): 44-49.

Smith, Mark S. "The Heart and the Innards in Israelite Emotional Expressions: Notes from Anthropology and Psychobiology." Journal of Biblical Literature 117/3 (1998): 427-436.

Smith, Mark S. and Wayne T. Pitard. Introduction with Text, Translation and Commentary of KTU/CAT 1.3-1.4. Volume 2 of The Ugaritic Baal Cycle. Leiden: Brill, 2009.

Steinert, Ulrike. Aspekte des Menschseins im Alten Mesopotamien: Eine Studie zu Person und Identität im 2. und 1. Jt. v.Chr. Cuneiform Monographs 34. Leiden: Brill, 2012.

. “'Zwei Drittel Gott, ein Drittel Mensch.' Überlegungen zum altmesopotamischen Menschenbild." Pages 59-81 in Der Ganze Mensch: Zur Anthropologie der Antike und ihrer europäischen Nachgeschichte. Edited by Bernd Janowski. Berlin: Akademie Verlag, 2012.

Van Wolde, Ellen. "Sentiments as Culturally Constructed Emotions: Anger and Love in the Hebrew Bible." Biblical Interpretation 16/1 (2008): 1-24.

Von Gemünden, Petra. "Methodische Überlegungen zur Historischen Psychologie exemplifiziert am Themenkomplex der Trauer in der Bibel und ihrer Umwelt." Pages 41-68 in Der Mensch im Alten Israel: Neue Forschungen zur alttestamentlichen Anthropologie. Edited by Bernd Janowski and Kathrin Liess. Herders Biblische Studien 59. Freiburg: Herder, 2009.

Vorwahl, Heinrich. Die Gebärdensprache im Alten Testament. Berlin: Dr. Emil Ebering, 1932.

Wälchli, Stefan H. Gottes Zorn in den Psalmen: Eine Studie zur Rede vom Zorn Gottes in den Psalmen im Kontext des Alten Testamentes und des Alten Orients. Orbis Biblicus et Orientalis 244. Fribourg: Academic Press, 2012.

Wagner, Andreas. Emotionen, Gefühle und Sprache im Alten Testament: Vier Studien. Kleine Untersuchung zur Sprache des Alten Testaments und seiner Umwelt 7. Waltrop: H. Spenner, 2006. . "Gefühl, Emotion und Affekt in der Sprachanalyse des Hebräischen." Pages 7-47 in Emotionen, Gefühle und Sprache im Alten Testament: Vier Studien. Edited by Andreas Wagner. Kleine Untersuchung zur Sprache des Alten Testaments und seiner Umwelt 7. Waltrop: H. Spenner, 2006. . "Eifern und eifersüchtig sein: Zur sprachlichen Konzeptualisierung von Emotionen im Deutschen und Hebräischen." Pages 75-100 in Emotionen, Gefühle und Sprache im Alten Testament: Vier Studien. Edited by Andreas Wagner. Kleine Untersuchung zur Sprache des Alten Testaments und seiner Umwelt 7. Waltrop: H. Spenner, 2006. . Anthropologische Aufbrüche: Alttestamentliche und interdisziplinäre Zugänge zur historischen Anthropologie. Forschungen zur Religion und Literatur des Alten und Neuen Testaments 232. Göttingen: Vandenhoeck \& Ruprecht, 2009. 
420 Kruger, "Emotions in the Hebrew Bible," OTE 28/2 (2015): 395-420

."Emotionen in alttestamentlicher und verwandter Literatur -

Grundüberlegungen am Beispiel des Zorns." Pages 27-68 in Emotions from Ben Sira to Paul. Edited by Renate Egger-Wenzel and Jeremy Corley.

Deuterocanonical and Cognate Literature Yearbook. Berlin: De Gruyter, 2011.

. "Mensch (AT)." No Pages in Das wissenschaftliche Bibellexikon in Internet

(WiBiLex): Alttestamentlicher Teil [cited 28 May 2015]. Edited by Michaela

Bauks and Klaus Koenen). Online: http://www.bibelwissenschaft.de/wibilex

/das-bibellexikon/lexikon/sachwort/anzeigen/details/mensch-at-3/ch

/6ee365028ad1b3e6a07698ed3eb7147d/.

Werbrouck, Marcelle. Les Pleureuses dans L'Égypte ancienne. Bruxelles: Éditions de la Fondation Égyptologique Reine Élisabeth, 1938.

Wierzbicka, Anna. Emotions Across Languages and Cultures: Diversity and Universals. Cambridge: University Press, 1999.

Wilce, James M. Language and Emotion. Cambridge: Cambridge University Press, 2009.

Wiseman, Donald J. Chronicles of Chaldaean Kings (626-556 B.C.) in the British Museum. London: Trustees of the British Museum, 1956.

Wolff, Hans Walter. Anthropologie des Alten Testaments. München: Kaiser Verlag, 1973.

Yoder, Christine Roy."The Object of Our Affections: Emotions and the Moral Life in Proverbs 1-9." Pages 73-88 in Shaking Heaven and Earth: Essays in Honor of Walter Brueggemann and Charles B. Cousar. Edited by Christine Roy Yoder, Kathleen M O'Connor, E. Elizabeth Johnson and Stanley P. Saunders.

Louisvale: Westminster John Knox Press, 2005.

Zwickel, Wolfgang."The Iconography of Emotions in the Ancient Near East and in Ancient Egypt." Pages 1-25 in Emotions from Ben Sira to Paul. Edited by Renate Egger-Wenzel and Jeremy Corley. Deuterocanonical and Cognate Literature Yearbook. Berlin: De Gruyter, 2011.

Paul A. Kruger, Department of Ancient Studies, University of Stellenbosch, Private Bag X1, Matieland, 7602.Email: pak@sun.ac.za. 